\title{
THE STATISTICAL ACCURACY OF THE POWER SPECTRUM OF THE SIGNAL OF HEART RATE VARIABILITY
}

\author{
A.N. Ragozin, ragozinan@susu.ru, \\ V.F. Telezhkin, telezhkinvf@susu.ru \\ South Ural State University, Chelyabinsk, Russian Federation
}

\begin{abstract}
Currently, spectral analysis occupies an important place among the various methods of investigation of heart rate variability. The result of the spectral analysis is a spectral power density of the study of heart rate variability, which serves as an indicator of the various mechanisms of regulation of the cardiovascular system. A common classical nonparametric method for calculating the spectral power density is the Welch periodogram method, with its underlying fast Fourier transform procedure. This method calculates and then averages a set of spectra obtained from timesequentially shifted segments of the initial dependence of heart rate variability. The resulting dependence of the spectral power density of the signal is a statistical estimate and characterizes the dependence of the distribution of the average power of the signal from the frequency. With this approach, the analyzed dependence of heart rate variability is considered as the realization of some random process. In this case, the amplitude of a peak of the dependence of the spectral power density is not associated with a constant amplitude (or its square) harmonics with a certain frequency and reflects a certain constant rhythm at this frequency, but is associated with the average measure of oscillatory activity (power) analyzed dependence heart rate variability at the frequency under consideration.

Keywords: heart rate variability, spectral analysis, Welch periodogram method, nonparametric method, spectral power density, oscillating processes, random processes.
\end{abstract}

\section{Introduction}

Currently, among the various methods of investigation of variability of heart rate variability (HRV) is important in spectral analysis [1-4]. The result of the spectral analysis is power spectral density (PSD) of HRV, which serves as an indicator of the different mechanisms of regulation of the cardiovascular system [1]. Common classical nonparametric method of calculation of the PSD is periodogram Welch method, with the underlying procedure Fast Fourier transform (FFT) - algorithm of fast calculation of the discrete Fourier transform (DFT) [5]. In this method, is calculated and then averaged set of spectra, obtained on sequentially offset in time segments depending source of HRV. The obtained dependence of the PSD signal is a statistical estimation and describes the dependence of the distribution of the average power of the signal (HRV) frequency. With this approach, we analyze the dependence of HRV is regarded as a realization of a random process (in the initial assumption of stationary, that is, on average, homogeneous in time and at constant time dispersion, average, etc.). In this case, the amplitude of any peak based on PSD not connected with constant amplitude (or its square) wave with a certain frequency and reflect some consistent rhythm at this frequency, and is related to the average measure of oscillatory activity (power) of HRV analyzed based on the considered. Numerical characteristics of PSD, reflects a measure of approximation of the studied process to the harmonic process is the coefficient of harmonization [6, 7]. An important characteristic of the calculated PSD (calculated spectrum) of HRV is based on the statistical validity of its values at different frequencies. As the final result of the spectral analysis of the dependence of PSD frequency is the result of averaging the sample spectra (periodogram), computed for shorter time intervals compared to the original signal, it is necessary to calculate also the dispersion of the values most important peaks of the resulting SPM. Because of the variability in time of the studied sample according to HRV spectra (periodogram) will vary in form. The variance of the values of any peak at the frequency of the resulting PSD (obtained by averaging the sample spectra) reflects the extent of the spread of values of peaks of the sample spectra in the considered frequency. When you reach a magnitude of dispersion of PSD peaks for specific values cannot be considered statistically significant [8]. For example, if the value of the root-mean-square estimation (RMSE) of a certain 
peak of PSD HRV exceeds the value of this peak, it is necessary to conclude that the considered peak of PSD HRV was formed not by a regular oscillation with a certain frequency present in the analyzed HRV dependence, but by a certain irregular sequence of single waves (bursts, The assessment of the balance of sympathetic or parasympathetic effects on the heart (simpatikus-parasimpatikus), as a rule, is associated with the regularity of various oscillations present in the investigated dependence of HRV. From the literature it is known the influence of irregular waves tachycardia induced by swallowing, in the form of PSD HRV in the low frequency region [2,4]. It is shown that the presence of such waves in the analyzed dependencies of HRV can distort the shape of PSD and lead to erroneous conclusions about the intensity of the sympathetic or parasympathetic influences on the heart. The control RMSE PSD can prevent erroneous conclusions. The appearance of random waves of any nature according to far will lead to an increase in RMSE expect PSD. Evaluation RMSE some peak PSD HRV on a specific frequency is an estimate of the measure of instability of the intensity oscillations at this frequency present in the analysed based on HRV. Informational role according RMSE PSD noted in [4].

\section{Modelling}

In Fig. 1 shows the temporary implementation of VSR with a duration of $200 \mathrm{~s}$, given a method of interpolation for uniformly sampled with a step of $0.4 \mathrm{~s}$. The known algorithm [1, 2]. In Fig. 2 shows the dependence of the SPM of the frequency of a given implementation of HRV calculated using periodogram Welch method, when the number of time segments $N=9$, segment duration $\Delta \tau c=40 \mathrm{~s}$ overlapping segments in time equal to $20 \mathrm{~s}$.

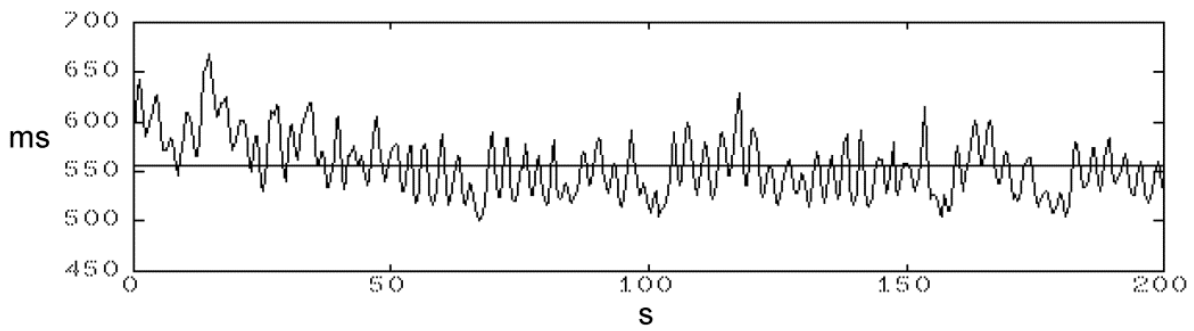

Fig. 1

PSD in Fig. 2 also shows the spectra in the frequency-time distribution (plane frequency-time) calculated for each of the nine relative to each other, sequentially offset in time of short segments of the initial implementation of the HRV (see Fig. 1). The average thus obtained nine spectra of the sample leads to a resultant according to PSD of HRV. Calculation of standard deviation values taken from nine sample spectra at each frequency of the whole frequency range leads to addiction RMSE PSD frequency, is also shown in Fig. 2 ( $\bar{S}_{1}, \bar{S}_{2}$ top right peaks PSD, $\sigma_{S 1} \sigma_{S 2}$ bottom right - peaks RMSE).
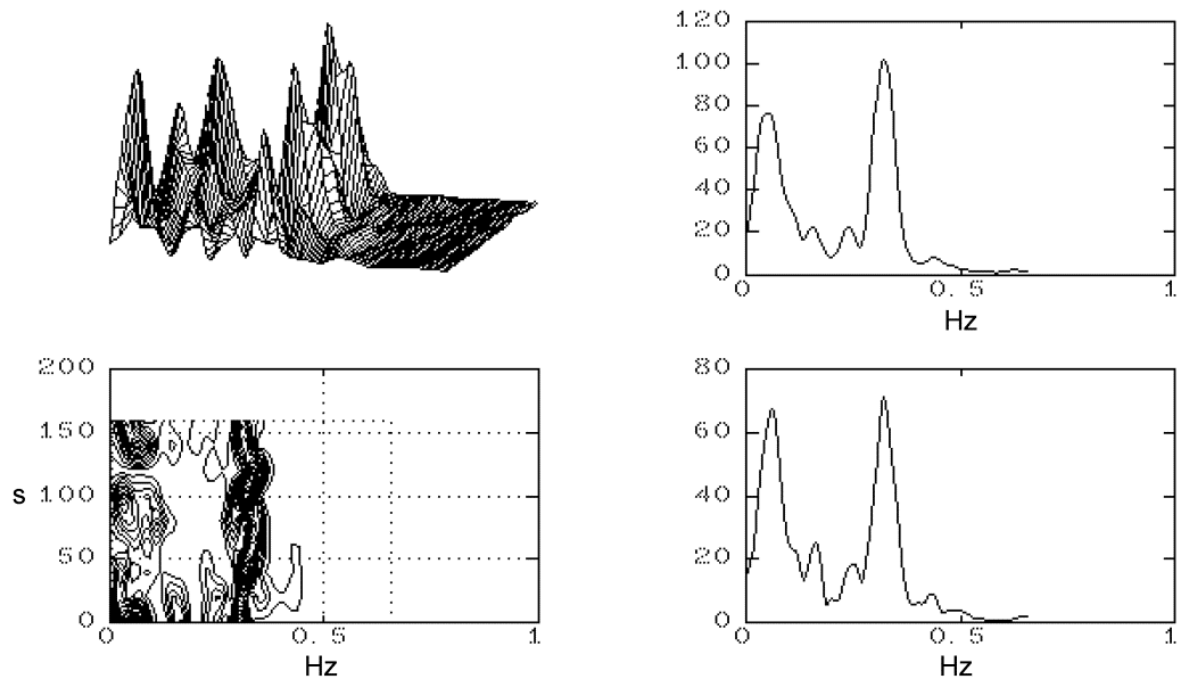

Fig. 2 


\section{Инфокоммуникационные технологии и системы}

The resolution in frequency $\Delta f p$ dependences PSD when $\mathrm{u}$ sing a weight function Hamming is $0.045 \mathrm{~Hz}$ in the General case is given by $\Delta f p \approx 1.8 / \Delta \tau c$. The dependency of PSD on the frequency of realization of HRV (see Fig. 1) contains two main peaks with values of $75 \mathrm{~ms}^{2} / \mathrm{Hz}$ and $105 \mathrm{~ms}^{2} / \mathrm{Hz}$, respectively. The values of standard deviation $\sigma_{s 1}, \sigma_{s 2}$, corresponding to peaks equal to $68 \mathrm{~ms}^{2} / \mathrm{Hz}$ and $71 \mathrm{~ms}^{2} / \mathrm{Hz}$. The intervals of the distribution of the amplitudes of $S_{1}$ and $S_{2}$ peaks of SPM (Fig. 2) with a confidence level of $90 \%$ determined by inequalities $32.84 \leq S_{1} \leq 117.16$ and $60.38 \leq S_{2} \leq 143.02$ respectively. The calculations were made according to the method [8]. The absolute value of the interval distribution is equal to $\Delta S_{1}=84.32 \mathrm{~ms}^{2} / \mathrm{Hz}$ and $\Delta S_{2}=88.04 \mathrm{~ms}^{2} / \mathrm{Hz}$. At the same time $\Delta S_{2} / \bar{S}_{2}=0.838$, $\Delta S_{1} / \bar{S}_{1}=1.124$, which is indicative of sufficiently large errors in the calculation of the amplitudes of the SPM peaks or about the large instability of the amplitudes of the vibrations reflected by these peaks. The value of the SPM ratio allows us to conclude that the oscillations of the HRV realization corresponding to the second peak of the PSD are relatively more stable, which is also evidenced by the dynamics of the variation of the sampling spectrum in time, shown in Fig. 2 (time-stable frequency band).

The excess in magnitude of the first peak of the PSD by the second can be explained by the more stable in amplitude character of the oscillations of the HRV reflected by the second peak in comparison with the oscillations corresponding to the first peak of the PSD. The maximum oscillation amplitudes corresponding to the first and second PSD peaks are approximately the same. It can be noted that the predominant factor forming the type of PSD in Fig. 2 is the ratio of the stability of the amplitude of the oscillations reflected by the peaks, and not the ratio of the maximum oscillation amplitudes. Without analyzing the dependence of RMSE PSD on frequency, such a conclusion can not be made (Fig. 3).

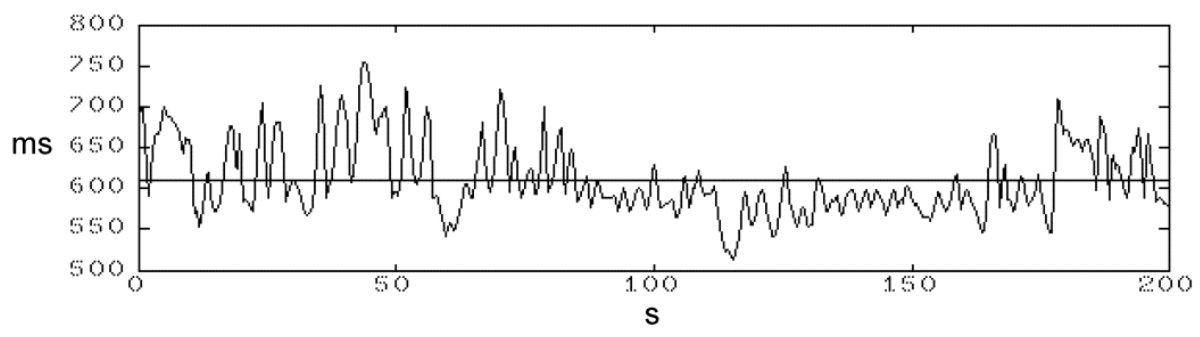

Fig. 3

The values of the SKO $\sigma_{s 1} \sigma_{s 2}$ corresponding to these PSD peaks are $300 \mathrm{~ms}^{2} / \mathrm{Hz}$ and $240 \mathrm{~ms}^{2} / \mathrm{Hz}$, which exceeds the values of the peaks $\bar{S}_{1}, \bar{S}_{2}$ PSD. In Fig. $4\left(\bar{S}_{1}, \bar{S}_{2}\right.$ top right peaks PSD, $\sigma_{S 1} \sigma_{S 2}$ bottom right - peaks RMSE) depicts the dependence of the PSD on the frequency of realization of the HRV (see Fig. 3) also containing two main peaks with the values $273 \mathrm{~ms}^{2} / \mathrm{Hz}$ and $125 \mathrm{~ms}^{2} / \mathrm{Hz}$, respectively.
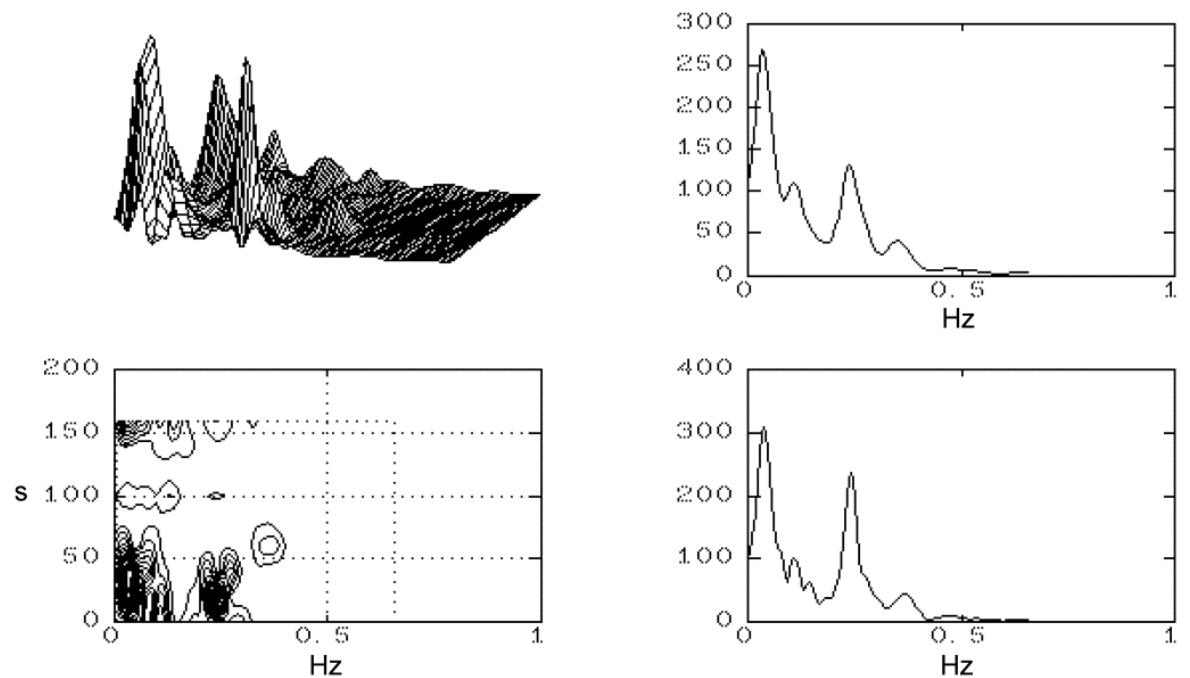

Fig. 4 
Therefore, the dependency of the PSD on Fig. 4, as well as the ratio of the magnitude of the main PSD peaks can not be considered statistically reliable. The dynamics of the change in the sample spectrum over time, shown in Fig. 4, indicates a considerable instability of the oscillations reflected by the main PSD peaks, which is a consequence of the nonstationarity of the process hown in Fig. 4. Fig. 6 ( $\bar{S}_{1}, \bar{S}_{2}$ top right peaks PSD, $\sigma_{S 1} \sigma_{S 2}$ bottom right - peaks RMSE) shows the dependence of the PSD on the frequency of HRV realization (Fig. 5), containing one dominant peak.

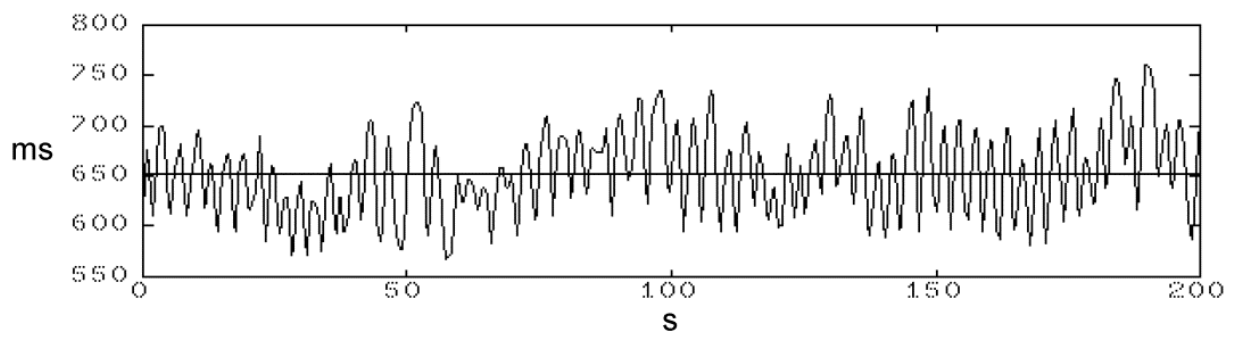

Fig. 5
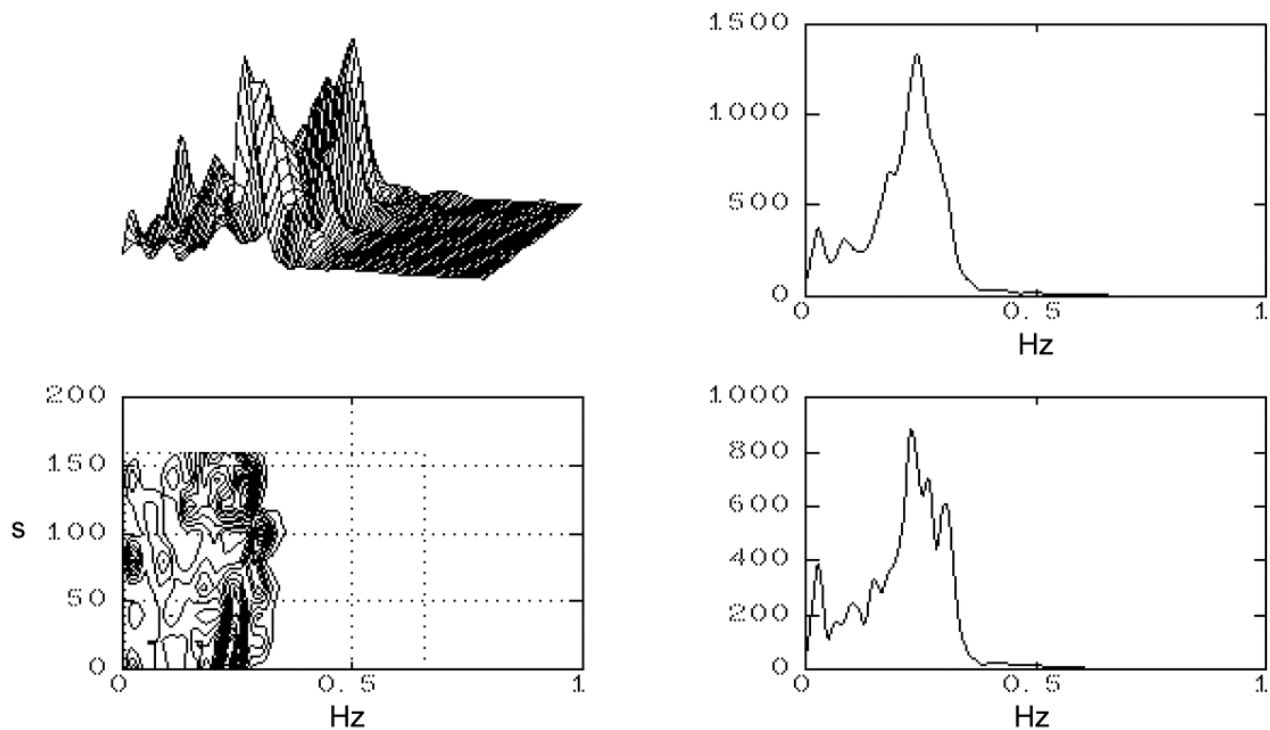

Fig. 6

The position in frequency of the maximum PSD size $1300 \mathrm{~ms}^{2} / \mathrm{Hz}$ does not coincide with the position of the frequency maximum of the RMS according to SPM is equal to $840 \mathrm{~ms}^{2} / \mathrm{Hz}$ and corresponds to the smaller value of RMSE approximately equal to $680 \mathrm{~ms}^{2} / \mathrm{Hz}$. The maximum PSD (fig. 6) due to the presence of narrow frequency bands relatively more stable oscillations that can be seen from the dynamics of changes in the sample spectrum. A wide frequency band of the main peak of PSD can be explained by the existence of unstable oscillations with frequencies in the vicinity of the frequency of maximum PSD. The dependency of PSD on the frequency of realization of HRV (Fig. 7), is shown in Fig. 8 ( $\overline{S_{1}}, \overline{S_{2}}$ top right peaks PSD, $\sigma_{S 1} \sigma_{S 2}$ bottom right - peaks RMSE), allows the identification of relatively stable low-frequency oscillations, as reflected by the peak of the PSD at the frequency of $0.04 \mathrm{~Hz}$ size $125 \mathrm{~ms}^{2} / \mathrm{Hz}$ (RMS equal to $62 \mathrm{~ms}^{2} / \mathrm{Hz}$ ). Against the background of unstable high frequency oscillations (peak value SPM $260 \mathrm{~ms}^{2} / \mathrm{Hz}$, the value RMSE - $285 \mathrm{~ms}^{2} / \mathrm{Hz}$ ).

The relatively low level of the low frequency peak PSD at the frequency of $0.04 \mathrm{~Hz}$ is not due to the small magnitude of the amplitude of the low-frequency oscillations at the frequency of $0.04 \mathrm{~Hz}$, but to the insufficient duration of the time segment $\Delta \tau c=40 \mathrm{~s}$. when calculating the sample spectra forming the Welch periodogram. The value of $\Delta \tau c=40 \mathrm{~s}$. leads to the value of the resolution at the frequency of PSD equal to $0.045 \mathrm{~Hz}$. Fluctuations with frequencies less than $0.045 \mathrm{~Hz}$ will not manifest themselves sufficiently on the PSD dependence. In the analysis of physiological signals (including time dependence far) except for the calculation based on the MTA required the calculation is also based on RMSE PSD 


\section{Инфокоммуникационные технологии и системы}

with estimation of confidence intervals of the distribution peak value PSD, the most important for physiological interpretation. This will prevent errors in interpretation resulting from analysis of the shape of PSD domains.

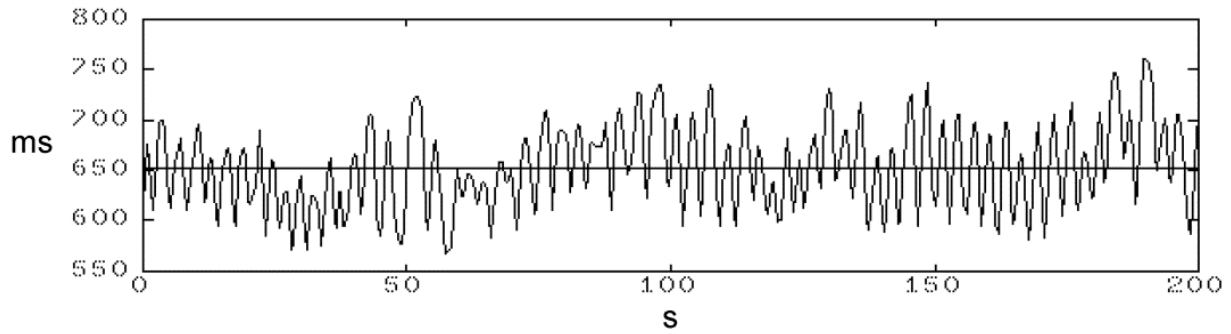

Fig. 7
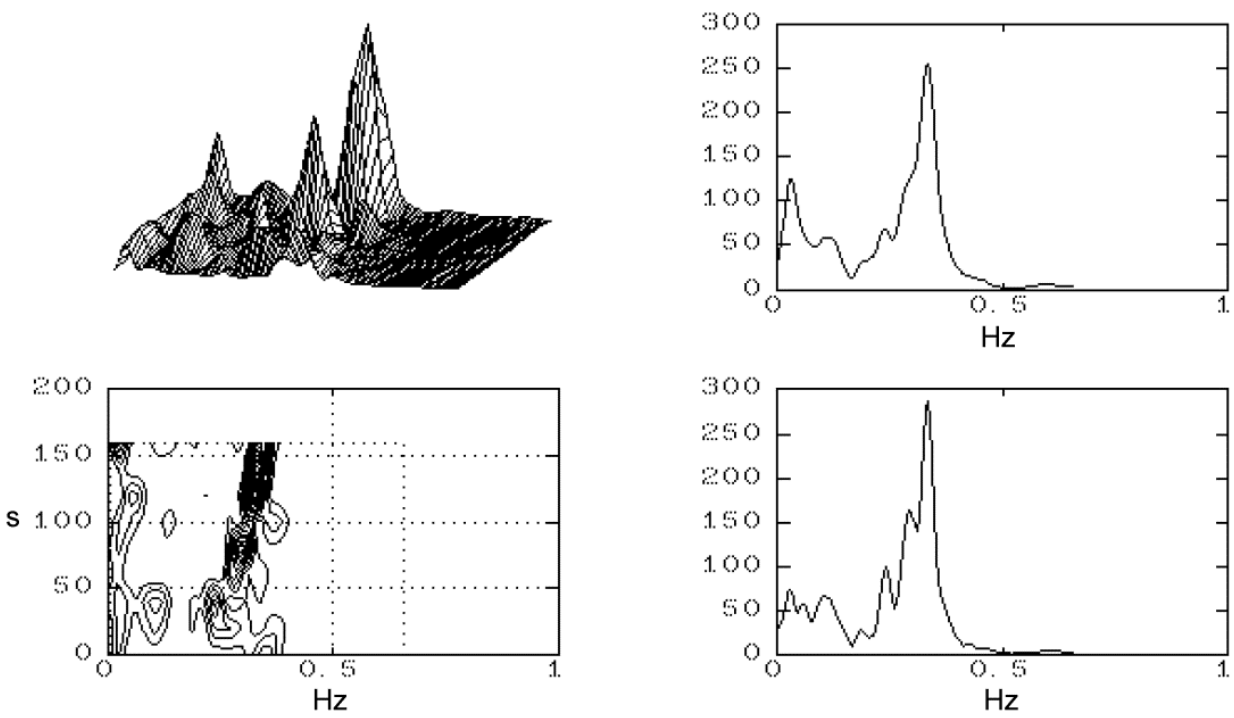

Fig. 8

\section{Conclusions}

Currently, among the various methods of investigation of variability of corection rate (HRV) is important in spectral analysis [1-4]. The result of the spectral analysis is power spectral density of HRV, which serves as an indicator of the different mechanisms of regulation of the cardiovascular system. The RMSE value of the analyzed peak SPM is a numerical assessment of the measure of instability of the intensity fluctuations in HRV, measured by the peak. In General, the dependence RMSE PSD frequency is an estimate of the measure of instability of the oscillations reflected by the HRV dependence of SPM and can have independent importance for the physiological interpretation. Calculation of statistical reliability of the PSD of HRV is performed in the version 2.0 computer program "Spectral analysis of physiological signals" [9].

\section{References}

1. Ryabykina G. V., Sobolev A.V. Variabel'nost' ritma serdtsa [Variability of a heart rhythm]. Moscow, Star'Ko Publ., 1998. 240 p.

2. Hayutin V.M., Lukoshkova E.V. [Spectral Analysis of Fluctuations of Frequency of Heartbeats: Physiological Bases and the Phenomena Complicating It]. Russian Physiological Journal of I.N. Sechenov, 1999, vol. 85, no. 7, pp. 893-909. (in Russ.)

3. Zulkarneev R.H., Kalikova S.A. [Clinical Value of a Research of Variability of a Warm Rhythm]. Health Care of Bashkortostan, 1998, no. 2-3, pp. 28-36 (in Russ.)

4. I Vserossiyskiy simpozium "Kolebatel'nye protsessy gemodinamiki. Pul'satsiya i flyuktuatsiya serdechno-sosudistoy sistemy”. Sb. nauchnykh trudov [I All-Russian symposium "Oscillatory Processes 
of Hemodynamics. Pulsation and Fluctuation of Cardiovascular System”. Coll. of. Scientific Works]. 30 May - 1 June 1, 2000, Miass. 340p.

5. Marple Jr. S.L. Tsifrovoy spektral'nyy analiz i ego prilozheniya [Digital Spectral Analysis and Its Applications]. Moscow, World Publ., 1990. 680p.

6. Ragozin A.N. [The Analysis of Spectral Structure of Nonstationary Physiological Signals on the Plane of Complex Frequencies]. Digital Radio-Electronic Systems (Online Journal), 1999, iss. 3, pp. 34-44. (in Russ.) Available at: http://www.prima.susu.ac.ru/drs/.

7. Ragozin A.N., Usynin A.M., Tokarchuk O.V., Kononov D.Yu. [Spectral Assessment of a Vegetative Tone of Pupils of High School. Digital Radio-Electronic Systems (Online Journal), 1999, iss. 3, pp. 127-130. (in Russ.) Available at: http://www.prima.susu.ac.ru/drs/.

8. Bendat J., Pirsol A. Prikladnoy analiz sluchaynykh dannykh [Applied Analysis of Casual Data]. Moscow, World Publ., 1989. 540p.

9. Ragozin A.N., Kononov D.Yu. Usynin A.N. Mikhaylov M.V. [Computer Program for the Spectral Analysis of Physiological Signals (Version 1.0)]. Digital Radio-Electronic Systems (Online Jour$n a l), 2000$, iss. 4, pp. 44-52. (in Russ.) Available at: http://www.prima.susu.ac.ru/drs/.

Received 5 May 2018

УДК $612.17(075.8)$

DOI: $10.14529 /$ ctcr180405

\title{
СТАТИСТИЧЕСКАЯ ДОСТОВЕРНОСТЬ СПЕКТРА МОЩНОСТИ СИГНАЛА ВАРИАБЕЛЬНОСТИ СЕРДЕЧНОГО РИТМА
}

\author{
А.Н. Рагозин, В.Ф. Тележкин \\ Южно-Уральский государственный университет, г. Челябинск, Россия
}

\begin{abstract}
В настоящее время среди различных методов исследования вариабельности сердечного ритма важное место занимает спектральный анализ. Результатом спектрального анализа является спектральная плотность мощности исследования вариабельности сердечного ритма, служащая в качестве индикатора различных механизмов регуляции сердечно-сосудистой системы. Распространённым классическим непараметрическим методом вычисления спектральной плотности мощности является периодограммный метод Уэлча, с лежащей в его основе процедурой быстрого преобразования Фурье. При этом методе рассчитывается и затем усредняется набор спектров, полученных на последовательно смещённых во времени сегментах исходной зависимости вариабельности сердечного ритма. Получаемая при этом зависимость спектральной плотности мощности сигнала является статистической оценкой и характеризует зависимость распределения в среднем мощности исследуемого сигнала от частоты. При таком подходе анализируемая зависимость вариабельности сердечного ритма рассматривается в качестве реализации некоторого случайного процесса. В этом случае амплитуда какого-либо пика зависимости спектральная плотность мощности не связана с постоянной амплитудой (или её квадратом) гармоники с определённой частотой и отражающей некоторый постоянный ритм на этой частоте, а связана со средней мерой колебательной активности (мощностью) анализируемой зависимости вариабельности сердечного ритма на рассматриваемой частоте.

Ключевые слова: вариабельность сердечного ритма, спектральный анализ, периодограммный метод Уэлча, непараметрический метод, спектральная плотность мощности, колебательные прочессы, случайные прочессы.
\end{abstract}

\section{Лuтература}

1. Рябыкина, Г.В. Вариабельность ритма сердиа / Г.В. Рябыкина, А.В. Соболев. - М.: Cтар'Ko, 1998. - 240 c.

2. Хаютин, В.М. Спектральный анализ колебаний частоты сердиебиений: физиологические 


\section{Инфокоммуникационные технологии и системы}

основы и осложняюшие его явления / В.М. Хаютин, Е.В. Лукошкова // Российский физиологический журнал им. И.Н. Сеченова. - 1999. - Т. 85, № 7. - С. 893-909.

3. Зулкарнеев, Р.Х. Клиническое значение исследования вариабельности сердечного ритма / Р.Х. Зулкарнеев, С.А. Каликова // Здравоохранение Башкортостана. - 1998. - № 2-3. - С. 28-36.

4. I Всероссийский симпозиум «Колебательные прочессы гемодинамики. Пульсация и флюктуачия сердечно-сосудистой системыл»: сб. науч. тр. 30 мая - Іиюня 2000 г. - Миасс, 2000. - 340 с.

5. Марпл-мл., С.Л. Цифровой спектральный анализ и его приложения / С.Л. Марпл-мл. - М.: Mup, 1990. $-680 \mathrm{c}$.

6. Рагозин, А.Н. Анализ спектральной структуры нестаџионарных физиологических сигналов на плоскости комплексных частот / А.Н. Рагозин // Цифровые радиоэлектронные системы (электронный журнал). - 1999. - Bыn. 3. - C. 34-44. - http://www.prima.susu.ac.ru/drs/.

7. Спектральная оченка вегетативного тонуса учашихся средней школь / А.Н. Рагозин, А.М. Усынин, О.В. Токарчук, Д.Ю. Кононов // Цифровые радиоэлектронные системы (электронный журнал). - 1999. - Bып. 3. - C. 127-130. - http://www.prima.susu.ac.ru/drs/.

8. Бендат, Дж. Прикладной анализ случайных данных / Дж. Бендат, А. Пирсол. - М.: Мир, 1989. $-540 c$.

9. Компьютерная программа для спектрального анализа физиологических сигналов (версия 1.0) / А.Н. Рагозин, Д.Ю. Кононов, А.Н. Усынин, М.В. Михайлов // Цифровые радиоэлектронные системы (электронный журнал). - 2000. - Bып. 4. - C. 44-52. - http://www.prima.susu.ac.ru/drs/.

Рагозин Андрей Николаевич, канд. техн. наук, доцент кафедры инфокоммуникационных технологий, Южно-Уральский государственный университет, г. Челябинск; ragozinan@susu.ru.

Тележкин Владимир Федорович, д-р техн. наук, профессор кафедры инфокоммуникационных технологий, Южно-Уральский государственный университет, г. Челябинск; telezhkinvf@ susu.ru.

Поступила в редакцию 5 мая 2018 г.

\section{ОБРАЗЕЦ ЦИТИРОВАНИЯ}

Ragozin, A.N. The Statistical Accuracy of the Power Spectrum of the Signal of Heart Rate Variability / A.N. Ragozin, V.F. Telezhkin // Вестник ЮУрГУ. Серия «Компьютерные технологии, управление, радиоэлектроника». - 2018. - Т. 18, № 4. - С. 52-58. DOI: $10.14529 /$ ctcr 180405

\section{FOR CITATION}

Ragozin A.N., Telezhkin V.F. The Statistical Accuracy of the Power Spectrum of the Signal of Heart Rate Variability. Bulletin of the South Ural State University. Ser. Computer Technologies, Automatic Control, Radio Electronics, 2018, vol. 18, no. 4, pp. 52-58. DOI: $10.14529 /$ ctcr180405 